\title{
THE CONSTITUTIONAL STATUS UP TO THE DEATH OF JOHN LACKLAND, KING OF ENGLAND
}

\author{
Assist. Lect. Samira Sha`lanQitan \\ Al-Mahmoudia Evening-Secondary School for Girls
}

DOI: $10.37648 / \mathrm{ijrssh} . v 10 \mathrm{i} 01.015$

Received:04 ${ }^{\text {th }}$ October, 2019; Accepted:01 ${ }^{\text {st }}$ November, 2019; Published: $26^{\text {th }}$ November, 2019

\section{INTRODUCTION}

The experience of the parliament of the United Kingdom represents a development example of the Democratic procedurethrough the Modern history. So, there isn't an experience come before this one and has a self-development as this which has happened in Britain. In Britain, there were social and economicconditions that represent an appearance and development of parliamentary life. Since 873 a united council, the Witian, has been in the custody of the Anglo-Saxon throne foundation, which contained who are close to the Royal Family in England, his action developed as a result of exploiting the need of successive kings for his services or the money of his members, so, they imposed their powers and conditions then increased at the expense of the throne.

The Witian began to engage in a kind of modest parliamentary activity, which reached the point of participating in the removal and inauguration of kings. When the Norman invasion came in 1066, this council was developed by the Conqueror William's need to legalize his occupation then changes its name to Common Concilum, which became a regular convening and became an official tradition as a result of the inability of kings to dispense with its advice. Whenever successive royal families went through harsh conditions, the sit-in took advantage of it and gained additional powers, so that the nobles could gain official recognition of the Council under Magna Carta in 1215.

\section{FIRST: CONSTITUTIONAL DEVELOPMENT IN ENGLAND UP TO 1199}

After the period of John I, constitution developed in England through the circumstances that faced by England, which helped in making the political and economic structure of England.

England (1) is considered one of the most important countries of the Western Europe that go

\footnotetext{
${ }^{1}$ The origin of England name, which was called the island which the ancients called Albion, which means white land, is not confirmed. It seems that its people themselves called themselves as Pritani or Priteni in the 4th century, which means tattooed people. So, there is a similar opinion that Pythese is one of the Greek visitors who reach to that island in 325 in the period of The Great Alexander (356-323) who described people there as Priteni that means coloured people by tattooed, this term has called by some of
} 
before the countries of other continent in the development of constitutional institutions since the Middle Ages (medieval period). The Iberians (Hispani) were considered the oldest members, who have come from Northern Spain by comparing them with Celts who have come from Central Asia, and then the Iberians communicate with native speakers in prehistorical period (2). Roman Empire have taken control of England about four centuries. Julius Caesar's military campaign (44-55 A.H.)is considered the first Romanian campaign, which aimed at stop the supports that were given to Celts' Gallic enemies, as well as his unquenchable desire for gains and wealth, to strengthen his military reputation and achieve personal glory. In 55 A.H., Julius Caesar has readied a marine campaign made up of eighty ships that carriedsoldiers and equipment, which moved through the English Channel (la Manche) and then conflicted with Celtic tribes that didn't achieve a complete victory to expose his Naval fleetto a severe storm lost him more ships, withdrew to lead another campaign in the following year, whereas he achieveda victory over the Celts and imposethe poll $\operatorname{tax}(3)$.

The Roman Empire has continued until the middle of the fifth century. When Germanic tribes' especially English people (Angelcynn), Saxons and Jute have invaded the British Isles since the early fifth century and after 100 years of conflict, seven kingdoms known as the sevenfold period were made in the 8th century, which are: Northumberland, Mercia, Wessex, East Anglia, Essex, Kent and Sussex. The term

Ancient Greek geographers such as Diodorus, Sicaulus, Strabo, Ptolmy et. al. when Julius Caesar takeover it, he recalled it as Britania according to those geographers. For more details, see: Muahib Adnan Muhammad, The Magna Carta and The beginnings of constitutional development in England1215-1225, unpublished master thesis, College of Education, Tikrit University, 2008.

${ }^{2}$ Mowat's Graphic History of Great Britain,Part.I. to 1603 , (London , 1930),P.7.

${ }^{3}$ Naeem Abdul Jouda, Evolution of the Parliamentary Institution in England until the Revolution of 1399, Unpublished Doctoral Thesis, University of Baghdad, College of Education/ Ibn Rushd, 2008, p. 1.
"England" is derived from the old English name "Englaland" that means "land of the Angles", which refers to the area that is called Britain in the past, which has covered by seven kingdoms in the 8thcentury (4).

Ecgberht (Egbert), the king of Wessex is considered the first King of England who taken control of seven kingdoms in 828. Then extend his influence on the other kingdoms, the conflict between Sussex kingdoms in the 8th century due to the influence established by the Kingdom of Mercia, which conflicted with the Kingdom of East Anglia, whereas the East Anglia could repulse the Mercian and prevented them from expanding in south of England as natural warriors capable of active resistance(5), not only because of its efficiency, but also because of religious and Danish influence. The Danish conquest began in the year $800 \mathrm{AD}$, and the invasions continued between the ninth and twelfth centuries and stayed under Danish control until the arrival of Edward in 1042, who has taken the control of English, and his period is considered the beginning of the occupation of England by William the Conqueror, the period of Edward is the transmission of ideas and customs of the Normandy and French culture, which made the king to replace the guardians with Normandy as well as brought Norman customs and traditions to the court (6), The situation worsened a lot after the abdication of the royal succession of England declared by princes of the kingdoms of Sussex ,Marsa , North Amerya and Anklya.The Council of Elders chose Harold Ben Godwin, Earl of Essex, as King of England, who had fears of the Normans and believed his intuition as William landed with his ship and his army in Pavency, one of the Sussex regions, and was subsequently attacked by Harold with a tired, incomplete army. As a result the Normans announced the victory at the Battle

${ }^{4}$ TalibMuhibis Hassan Al-Waeli, King and Baron features parliamentary life in Britain 1066-1949, 1st edition, Rand Printing and Publishing House, Damascus, 2011, p. 27.

${ }^{5}$ Muahib Adnan Ahmed Muhammad, Ibid, p. 15.

${ }^{6}$ Musa Muhammad Al-Twerash, Democratic Development in Britain 1066-1911 Lessons in Patriotism and Peaceful Construction of Democracy, Adnan House and Library, Baghdad, 2013, p. 34.

\section{INTERNATIONAL JOURNAL OF RESEARCH IN SOCIAL SCIENCES AND HUMANITIES}


of Hastings on 14 October $1066 \mathrm{AD}$ and the William ascended the throne of England, and to legitimize the Kingdom of England In order to legitimize the kingdom, William the Conqueror summoned the Council of Elders (Wattian)(7) to meet and to force them to elect him.In 1066 William the Conqueror considered himself the legitimate heir to the rule of England(8).William asked the Council of Elders toregular meetings three times per-year on the three feasts (Easter, Christmas, Pentecost), desiring to put an end between the pre-Island and Normandy periods, in 1066, the year of conquest or occupation, it was the official date for changing the name of the Council of Elders to the Common Concilum(9).

The opinions of the influence of the two councils were diverged;they considered the king's council as a different group from the Common Concilum, while the historians Munro mentioned that the two councils form one chamber with no difference between them. It seems that the reasons for the contradiction regarding the competence of the two councils;lies in:

1. The meetings of the common council were broken meetings at three specific times and places of the year.

\footnotetext{
${ }^{7}$ Whitan: The Latin term means the Council of Elders or wise men, it has many meaning as the Council of State or the General Assembly, which includes a group of wise men or free wise men, its organization is not entirely clear at the beginning of its creation, as it was very small and as an aristocratic association that constitutes For the wise men and nobles of the Kingdom, its members included members of the royal family, the Irish, the Earls, the archbishops, the heads of the monasteries, bishops, priests, as well as members who call themselves servants, assistants and men of the King. For more detail see: Steinberg and Havans, Steinberg's Dictionary of British History, London, Edward Arnoild, 1970, P.405; Stubbs, William, The constitutional History of England, Oxford, at the Cloredon Press, 1891, Vol.1, P.140.

${ }^{8}$ Abdel Qader Ahmed Al-Yousef, European Middle Ages, Modern Library, Beirut, p. 171.

${ }^{9}$ 9. Saai'd Abdel Fattah Ashour, Medieval Europe, part 1, Anglo-Egyptian Library, Cairo, 2009, pp. 439-440.
}

2. The king's council made a staff of authority, executive council or judicial court, which made the king able to form a royal council that belong to the king and follow his orders.

3. The King's desire to delegate the most loyal elite to his ambitions of the members of the common council and including them as courtiers of the king.

The importance of the King's Council in the Normans period became more than the common council, the last of which was limited to formal administrative and political aspects, while the King's authorities focused on the financial such as; taxation and judiciary aspects such as; listening and discussing to the court cases in all the courts of the country, in order to discriminate in political, administrative, judicial and financialaspects (10).

Therefore, these three councils: the Council of Elders, the common Council and the King's Council have historically developed in order to support the king of England and advise him to solve the problems that faced by the country. The turmoil to separate if exceeded the influences and this is what happened in several cases, so these influences applied by the Council of Elders in the era before the conquest of Normandy (11).

As these three councils accompanied the appearance of the jury system and the Circuit courts, these jurors contributed to obtaining important information in order to make the right decisions, so there were some missions sent to the provinces in order to meet the population, and provide them with information that they find appropriate or harmful for them. These information be related with their performance in transporting information in order to present the articles which are prepared by the mission. The performance and the main job of the jurors which was transferring information from the community tothe king and as the opposite(12).They specialized in collecting taxes and disputes relating to

\footnotetext{
${ }^{10}$ Saai'd Abdel Fattah Ashour, Ibid, p. 440.

${ }^{11}$ Muahib Adnan Ahmed Muhammad, Ibid, p. 18.

${ }^{12}$ Naeem Abdul Jouda, Ibid, p. 30.
} 
funds and tracking cases of fraud in the work of supervision and the work of other financial officials. In addition, these missions carried out a large-scale survey in England in 1085 for all regionsand villages by recording the answers of the jurors in those villages, and focused most of the questionnaires on the side. Economically, however, the jury system continued the development of representative institutions in England prior to the issuance of the Magna Carta, and contributed to the first foundations of constitutional developments in England (13). The Magna Cartawas formed a development of political institutions in the Middle Ages as well as for later periods, these developments were a mixture of local English traditions of new ideas that came from the Germanic tribes, whereas there were many councils such as the Folk Mut Council and the Special Council of Elders In the Kasbah, the Shermut and the Wider Council of Elders of the Province, then came The Watians, who included representatives of the former Ruling Council of the Kasbah and the Province, the authority of the Waatyan Council was:

1. Appointing kings and removing them in exceptional cases.

2. Taking his agreement when issuing kings to legislation and laws.

3. Participation with the kings in the appointment of heads of provinces and heads of bishops.

4. Kings consult with him during the granting of public land and the imposition and collection of taxes and the conclusion of treaties and the declaration of the state of war and peace.

5. Kings are considered as court for criminal and civil cases.

Henry II of England is considered the most famous of judicial reform in England, the Clarendon Assize act the first legal regulation issued by the Council held in Clarendon in February 1166, it is noted that visits by circuit courts have become regular and

\footnotetext{
${ }^{13}$ Nadhir Hassan Saadawi, History of England and Its Civilization in Antiquity and the Middle Ages, Egyptian Renaissance Library, Cairo, 1958, p. 70.
}

included twenty-two articles that the first six concerning with the twelve jurors and investigation way.The text of the first article is "King Henry II has the right to form missions of movable judges to investigate many provinces in order to preserve peace and justice". King Henry II allowed them to meet with twelve jurors in each village to report the truth after swearing, the nineteenth article of the constitution was entrusted the task of coordinating among the jurors and judges who move to county to supervision, requiring the others to gather jurors and monitor the investigation process(14).

The King and his chancellors participated in the forming of this rule in the council, which contained archbishops, bishops, masters of monasteries and earls in all of England, and the general commandment was implemented in the same year, two judges, Earl of Essexand Richard De Lucy acted as circuit judgeseverywhere in England, their procedures and investigations had filled the royal files of that year in unusually way. Northampton Assize largely based on the Assize of Clarendon of 1176, which has had a large impact on the development of the jury system. It is a rewrite and expansion of the Clarendon Act, which has increased the powers granted to mainly circuit judges. There is no doubt that he was associated with the organization of the circuit courts, as in his instructions in the thirteen articles, the division of the Kingdom into six judicial rounds, for each round three judges circuit, it must be noted that this rule contains a number of punishments that should be imposed on the perpetrators and jurors who are lie in Oath, which is a new text that has referred by in the ancient law (15).

It appears that the jury system took a representative form in the visits law in 1194, anywhere the jurors were chosen according to the great law that mentioned above, so choice based on three steps:In the first step, four knights or free people are elected in the province. In the second step, they choose two of knights or free people to form with them the twelve jurors who were representing the 100 . In the third step, these two

\footnotetext{
${ }^{14}$ Muahib Adnan Ahmed Mohammed, Ibid, p. 30.

${ }^{15}$ Muahib Adnan Ahmed Mohammed, Ibid, p. 36.
}

\section{INTERNATIONAL JOURNAL OF RESEARCH IN SOCIAL SCIENCES AND HUMANITIES}


knights choose ten knights or free people in order to make a group consists of 12 jurors who were representing of one hundred (16).

\section{SECOND: THE CONSTITUTIONAL STATUS IN THE ERA OF JOHN I, KING OF ENGLAND}

In the era of John I, England lived in an important period in some respects that differed from the previous one. So, the new situations under King John eased the way towards the Magna Carta.

Although the idea of Virtual representation is older than the parliament, so the jury system later had a significant impact on the development of popular representation in front of the king, who found it convenient to meet with representatives in a predetermined place instead of sending his representatives or sending circuit courts to various provinces. In 1204 , when King John (1199-1216) ordered 12 men from each of the five ports to be summoned to a certain place to discuss trade issues with royal responsibility.

The importance of the King's Council during the period of the Norman kings exceeded the common Council, which its functions were limited to administrative and political formalities, while the terms of reference of the King's Council were focused on the financial aspects of collecting taxes and the judiciary aspects to discuss cases in the courts of the country to begin Discrimination in political, administrative, judicial and financial aspects. However, the common council rapidly regained its importance, which seemed more apparent, especially in the mid of twenty third century, after King John (1167-1216) plunged his country into many foreign (crusader) and internal (feudal) wars as well, and pursued authority with the nobles, then entered into a major conflict with the Church on the appointment of archbishop of Canterbury and his desire to take the properties (17).

King John's many wars led to the bankruptcy of the treasury, encouragement him to impose new taxes to hide his military expenses. Both church

\footnotetext{
${ }^{16}$ Naeem Abdul Jouda, Ibid, p. 37.

${ }^{17}$ Nadhir Hassan Saadawi, Ibid, 92.
}

representatives and senior feudal leaders rejected the taxation, emphasizing the principle of: ((No new taxes without their agreement, no money without improvement))(18).It's clearly that the rejection of the church representatives and elder feudalists of King John's tax legislation, finally, the rejection of the principle of taking their agreement and restructuring, forced him to increase and diversify the members of the commoncouncil by involving new members, in order tobanish the opposition of the church representatives and elder feudal to put members of his supporters extending himwith the necessary funds for their membership on the one hand, the parliamentary representation has begun of new parts in the common council on the other hand.

Then the King John wrote to his control states on November 7, 1213 about: ((It is necessary to bring four of smart knights in your states to join with the meetings of common council, which will be in Oxford on 15 November to discuss matters concerning with the affairs of our kingdom)) (19).To work as the first sign of the principle of parliamentary representation (20).

The matter that confusion worse confounded is the disagreements between them, The King's increased need for financial incomes in order to cover his foreign wars that was military defeats, the most important of

\footnotetext{
${ }^{18}$ Adams, George Burton, Constitutional History of England, London, Jonathan Cape, 1948, PP.169-215.

${ }^{19}$ Maitland , F.W., The Constitutional History of England, Cambridge, at the Univ. Press, 1950, P.68, Marriott, John, A.R., English Political Institution , Oxford, at the Clarendon Press, 1938, P.68.

${ }^{20}$ Although the ambiguity of the King's book to his commissioners and his lack of reference to how to select the wise knights from the provinces, and the ambiguity of the instructions on the mandatory summoning of a certain number of cavalry minds, and the interrogation of who to bear the expenses of their travel to Oxford meeting headquarters, but that invitation was the beginning of representation for parliamentarians and distant historical assets of representation in parliament. For more details, see: Nadhir Hassan Saadawi, Ibid, p. 93.
} 
which was the Battle of Bouvines(21), which was near to Lille city in 1214. So, the efforts of the nobles of the country to face King John, and they submitted a list of their demands to him, delayed in accepting it, aiming to receive the support of the church men and Londoners against the nobles, which led them to conflict with the king's armies in the province of Runnymede near Windsorin a battle that finished with factory and taking over London and forcing King John to sign and seal their demands in a document called Magna Carta on Monday, June 15, 1215 (22).

The Magna Carta that contained 63 articles divided into four parts: the first part made up of one article, which determine the relationship between church and crown (Papal tiara), in which the king John recognized to the clergy men their full privileges and dealt with their rights and their duties, the second part consisted of 15 articles, which dealt with the relations between the king and his followers, while the third consisted of 35 articles, which dealt with the following procedures in the case of the judgment of civil cases between the king and his citizens, the forth part

${ }^{21}$ Boffin: This battle was between King John and his associates on the one hand, and King Philip II of France and his associates on the other. The battle began when King John, with his warriors, made an attack on northern France in order to recover his lost property on the European continent. The battle took place in the town of Boffin, which located between the cities of Lille and Turin. The battle ended with the defeat of King John and his associates, and the results led to the elimination of King John's ambitions to regain his property on the European continent, as well as the opposition of the Barons of England to the king's projects in military service outside England, and his demands for taxation to cover the expenses of the war. See: Steinberg op.cit., P.12.

22. Austin Lane, from Domesday book to Magna Carta 1087- 1215, Oxford, at the Clarend press, 1915 , pp. 473- 474.

${ }^{22}$ Austin Lane, from Domesday book to Magna Carta 1087- 1215, Oxford, at the Clarend press, 1915 , pp.

473- 474. consisted of 12 articles, which dealt with the full Baronies rights (23).

One of the most important articles of the Magna Carta isarticle 12, which referred to its legislative authorities after it confirmed on((the king did not collect aids or war services allowance - in addition to the feudal funds established - without the agreement of the Common Council)). Article No. 14, which referred to the system of the council's rules of procedure which contained ((the Council shall hold its meetings by means of sending sealed letters to the archbishops and to the heads of the monasteries, earls and senior barons to invite them on a particular day and place... so that the invitation is made at least 40 days in advance... The purpose of the meeting is specified in the invitation letters... They are summoned in their names exclusively, and the young barons and knights are summoned under invitations sent to the king's provincial agents for the purpose of supervising their election)) Article No. 39, which represents a qualitative move in the development of the English political system, affirms the principle of personal freedom and provides for guarantees to protect it, by affirming that ((It's forbidden to arrest any free person, deprived of his/her property, deported or harmed in any way except by authority issued by those who are the responsible of the country ))(24).

To apply the articles of the contract and put into effect, article 61 approved this matter, and stipulated that twenty-five barons should be appointed, whose task is to implement the conditions that the King has pledged to observe in the contract and to oblige it to abide by them, even if the use of force is required against him ((if we do not correct the violation or if a judge doesn't judge in case we are absent outside the Kingdom so,it is the right of the 25 members or all the people in the Kingdom to detain and restrict us by all possible ways, by confiscating our palaces, our lands and other properties, until the violation is

\footnotetext{
${ }^{23}$ Nadhir Hassan Saadawi, Ibid, 93.

${ }^{24}$ Quatedin:Howared, A. E. Dick, Magna Carta, Text and Commentary ,Newyork, uni. press, 1964, p.33.
} 
corrected, this does not involve harming us, the kingdom or our children))(25).

Thus, the developments of that era culminated in the Magna Carta, which chronicled the various forms of injustice that led to the forced rebellion against the king, as well as a new era in the relationship between the throne and some class groups barons, the great landowners representatives of the feudalism suppers and the clergy men after absolute ownership has been transformed into a restricted and somewhat specific advisory property, which concerning with taxation. It is also at the forefront of the great documents, which serve as a starting point and a real beginning in the development of the English parliamentary institution, for a number of reasons, including:

1. The general public was motivated to demanding their rights to the barons, as did their demands towards King John.

2. The problems of the era in which they were issued were embodied, and the way in which contemporaries thought of addressing those problems.

3. The circumstances in which they were written and formed have given them special importance for future generations, in order to follow the example of their ancestors to demanding their rights according to the royal institution, even as it is a milestone in the history of the English Parliament (26).

\section{CONCLUSION}

The Constitutional developmentsin England before the period of John I; have helped to form the political and economic structure of England. When the Germanic tribes went to invasion the British Isles since the early fifth century, and in the $8^{\text {th }}$ century, the Heptarchy is a collective name applied to the seven kingdoms of Anglo-Saxon England in 828, but the Heptarchy didn't continue, so after October $14^{\text {th }} 1066$,

\footnotetext{
${ }^{25}$ Bailey, Sydney, English Parliamentary Democracy, Translated by Farouk Youssef Ahmed, Cairo, AngloEgyptian Library, 1970, p. 60.

${ }^{26}$ Nadhir Hassan Saadawi, Ibid, 95.
}

William became the king of England. Therefore, in order to make his authority lawful, he called the Council of Elders or wise men (Whitan) to make a meeting and force them to elect him, so he considered himself the rightful heir of England. He made the Council of Elders hold three times a year and was named the common Concilm, and he made another council which was called as 'The Council of the Kind' that was as stuff of authority, the Executive Council or judicial branch (court system) that make the king in any time able to form a small council Kind, which obeys his orders. So, his interests focused on the financial, taxing, taxation aspects discuss the cases in all the courts of the country to show excellence in political and administrative, judicial and financial issues. Over the time, these councils have developed historically and provided advices to the King and solve some problems which faced the country. This system was a continuation to develop the representative institutions in England before the issuance of the Magna Carta, through the period of King Jon I, the developments of that period culminated in the issuance of the Magna Carta on June $15^{\text {th }}, 1215$, which write the different types of atrocities as well as, the beginning of a new period among the throne, some classes barons and feudal representatives that considered a real beginning to develop the parliament of England (Agora Portal).

\section{NOTES}

1. The origin of England name, which was called the island which the ancients called Albion, which means white land, is not confirmed. It seems that its people themselves called themselves as Pritani or Priteni in the 4th century, which means tattooed people. So, there is a similar opinion that Pythese is one of the Greek visitors who reach to that island in 325 in the period of The Great Alexander (356-323) who described people there as Priteni that means coloured people by tattooed, this term has called by some of Ancient Greek geographers such as Diodorus, Sicaulus, Strabo, Ptolmy et. al. when Julius Caesar takeover it, he recalled it as Britania according to those geographers. For more details, see: Muahib Adnan Muhammad, The Magna Carta and The beginnings of constitutional development in

\section{INTERNATIONAL JOURNAL OF RESEARCH IN SOCIAL SCIENCES AND HUMANITIES}


England1215-1225, unpublished master thesis, College of Education, Tikrit University, 2008.

2. Mowat's Graphic History of Great Britain,Part.I. to 1603 ,(London , 1930),P.7.

3. Naeem Abdul Jouda, Evolution of the Parliamentary Institution in England until the Revolution of 1399, Unpublished Doctoral Thesis, University of Baghdad, College of Education/ Ibn Rushd, 2008, p. 1.

4. TalibMuhibis Hassan Al-Waeli, King and Baron features parliamentary life in Britain 1066-1949, 1st edition, Rand Printing and Publishing House, Damascus, 2011, p. 27.

5. Muahib Adnan Ahmed Muhammad, Ibid, p. 15.

6. Musa Muhammad Al-Twerash, Democratic Development in Britain 1066-1911 Lessons in Patriotism and Peaceful Construction of Democracy, Adnan House and Library, Baghdad, 2013, p. 34.

7. Whitan: The Latin term means the Council of Elders or wise men, it has many meaning as the Council of State or the General Assembly, which includes a group of wise men or free wise men, its organization is not entirely clear at the beginning of its creation, as it was very small and as an aristocratic association that constitutes For the wise men and nobles of the Kingdom, its members included members of the royal family, the Irish, the Earls, the archbishops, the heads of the monasteries, bishops, priests, as well as members who call themselves servants, assistants and men of the King. For more detail see:Steinberg and Havans, Steinberg's Dictionary of British History, London , Edward Arnoild, 1970, P.405; Stubbs, William, The constitutional History of England, Oxford, at the Cloredon Press, 1891, Vol.1, P.140.

8. AbdelQader Ahmed Al-Yousef, European Middle Ages, Modern Library, Beirut, p. 171.

9.Saai'd Abdel Fattah Ashour, Medieval Europe, part 1, Anglo-Egyptian Library, Cairo, 2009, pp. 439-440.

10.Saai'd Abdel Fattah Ashour, Ibid, p. 440.
11.MuahibAdnan Ahmed Muhammad, Ibid, p. 18.

12.Naeem Abdul Jouda, Ibid, p. 30.

13.Nadhir Hassan Saadawi, History of England and Its Civilization in Antiquity and the Middle Ages, Egyptian Renaissance Library, Cairo, 1958, p. 70.

14.Muahib Adnan Ahmed Mohammed, Ibid, p. 30.

15.Muahib Adnan Ahmed Mohammed, Ibid, p. 36.

16. Naeem Abdul Jouda, Ibid, p. 37.

17. NadhirHassanSaadawi, Ibid, 92.

18. Adams, George Burton, Constitutional History of England, London, Jonathan Cape, 1948, PP.169-215.

19.Maitland , F.W., The Constitutional History of England, Cambridge, at the Univ. Press, 1950, P.68, Marriott, John, A.R., English Political Institution , Oxford, at the Clarendon Press, 1938, P.68.

20.Although the ambiguity of the King's book to his commissioners and his lack of reference to how to select the wise knights from the provinces, and the ambiguity of the instructions on the mandatory summoning of a certain number of cavalry minds, and the interrogation of who to bear the expenses of their travel to Oxford meeting headquarters, but that invitation was the beginning of representation for parliamentarians and distant historical assets of representation in parliament. For more details, see: NadhirHassanSaadawi, Ibid, p. 93.

21.Boffin: This battle was between King John and his associates on the one hand, and King Philip II of France and his associates on the other. The battle began when King John, with his warriors, made an attack on northern France in order to recover his lost property on the European continent. The battle took place in the town of Boffin,which located between the cities of Lille and Turin. The battle ended with the defeat of King John and his associates, and the results led to the elimination of King John's ambitions to regain his property on the European continent, as well as the opposition of the Barons of England to the king's 
projects in military service outside England, and his demands for taxation to cover the expenses of the war. See: Steinberg op.cit., P.12.

22. Austin Lane, from Domesday book to Magna Carta 1087- 1215, Oxford, at the Clarend press, 1915 , pp. 473- 474.

23. Nadhir Hassan Saadawi, Ibid, 93.

24. Quatedin:Howared, A. E. Dick, Magna Carta, Text and Commentary ,Newyork, uni. press, 1964, p.33.

25. Bailey, Sydney, English Parliamentary Democracy, Translated by Farouk Youssef Ahmed, Cairo, AngloEgyptian Library, 1970, p. 60.

26. Nadhir Hassan Saadawi, Ibid, 95.

\section{REFERENCES}

\section{First: Master Theses and Doctoral Dissertations}

1. Muahib Adnan Muhammad, The Magna Carta and The beginnings of constitutional development in England1215-1225, unpublished master thesis, College of Education, Tikrit University, 2008.

2. Naeem Abdul Jouda, Evolution of the Parliamentary Institution in England until the Revolution of 1399, Unpublished Doctoral Thesis, University of Baghdad, College of Education/ Ibn Rushd, 2008.

\section{Second: Arabic Books}

1. Bailey, Sydney, English Parliamentary Democracy, Translated by Farouk Youssef Ahmed, Cairo, AngloEgyptian Library, 1970.

2. Saai'd Abdel Fattah Ashour, Medieval Europe, part 1, Anglo-Egyptian Library, Cairo, 2009.

3. TalibMuhibis Hassan Al-Waeli, King and Baron features parliamentary life in Britain 1066-1949, 1st edition, Rand Printing and Publishing House, Damascus, 2011.

4. Abdel Qader Ahmed Al-Yousef, European Middle Ages, Modern Library, Beirut.
5. Musa Muhammad Al-Twerash, Democratic Development in Britain 1066-1911 Lessons in Patriotism and Peaceful Construction of Democracy, Adnan House and Library, Baghdad, 2013.

6. Nadhir Hassan Saadawi, History of England and Its Civilization in Antiquity and the Middle Ages, Egyptian Renaissance Library, Cairo, 1958.

\section{Third: English References}

1- Adams, George Burton, Constitutional History of England, London, Jonathan Cape, 1948 .

2- Austin Lane, from Domesday book to Magna Carta 1087- 1215, Oxford, at the Clarend press, 1915.

3- Maitland , F.W., The Constitutional History of England, Cambridge, at the Univ. Press, 1950.

4- Marriott, John, A.R., English Political Institution , Oxford, at the Clarendon Press, 1938 .

5- Quatedin:Howared, A. E. Dick, Magna Carta, Text and Commentary ,Newyork, uni. press, 1964.

6- Steinberg and Havans, Steinberg's Dictionary of British History, London, Edward Arnoild .

7- Stubbs, William, The constitutional History of England, Oxford, at the Cloredon Press, 1891, Vol.1 . 